' 'دانشجوى كارشناسى ارشد، يرديس فنى و مهندسى، گروه مهندسى كاميوتر، دانشگاه يزد،

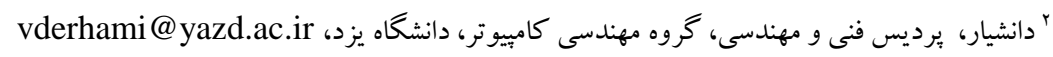

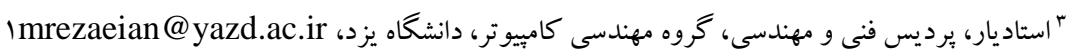

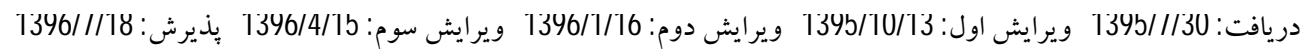

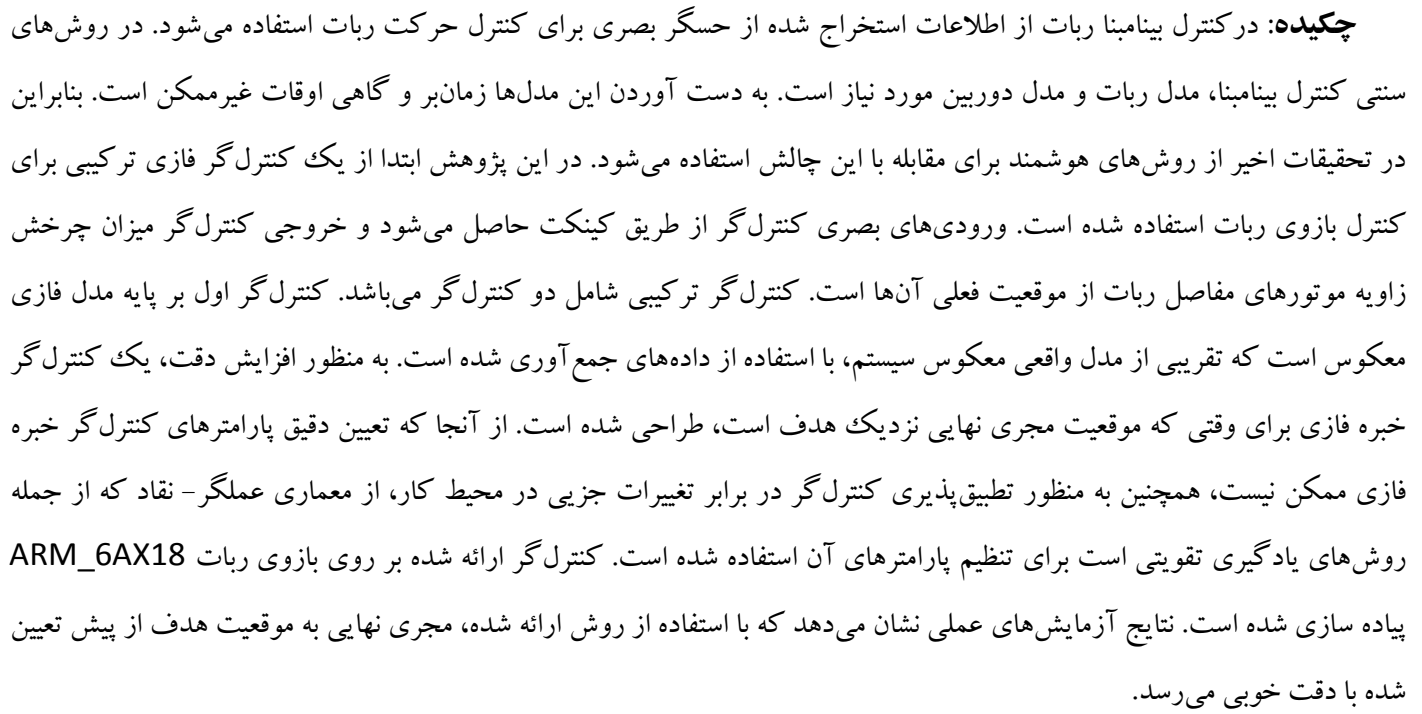
كلمات كليدى: كتترل بينامبنا، سيستم فازى، مدل معكوس فازى، بازوى ربات، ياد كيرى تقويتى، عملكر -نقاد

\title{
Designing a Fuzzy Controller for Visual Servoing of a Robot Manipulator with Online Adjustment Capability
}

\author{
Fatemeh Abadianzadeh, Vali Derhami, Mehdi Rezaeian
}

\begin{abstract}
Vision-based robot control is a method to motion control of a robot using information extracted from visual sensors. In traditional approaches, a model of robot and camera are needed. Obtaining these models are time consuming and sometimes impossible. Recently, intelligent methods are used to cope the above challenges. In this paper, a hybrid fuzzy controller is proposed to control a robot manipulator. Visual inputs of the controller are provided by Kinect and outputs are the rotation of joints motors. The hybrid controller contains two controllers. The first controller in based on fuzzy inverse model which approximates real inverse model of robot using gathered data. In order to increase accuracy, a fuzzy expert controller is designed and it is used when the endeffector is in the predefined near-goal area. Since determining exact value of the fuzzy expert controller parameters is impossible, in addition to make system adaptive with small changes in the environment, actor-critic architecture is used. This architecture is a well known continuous
\end{abstract}


reinforcement learning methods. The proposed method is applied to control a real robot manipulator (ARM_6AX18). Experimental results show that using the proposed method in practice, the endeffector reaches from any random start position to the goal position with a good accuracy in robot workspace.

Keywords: Visual servoing, Fuzzy systems, Fuzzy inverse model, Robot manipulator, Reinforcment learning, Actor-critic.

از حالشهاى بيشرو در اين روش معكوسيذير نبودن ماتريس زاكوبين است. علاوه بر آن براى محاسبه ماتريس زاكوبين نياز به دانستن بارامترهاى دوربين نيز است. در [ץ] از وبكم ساده براى تصوير بردارى و استخراج ويزُخى ها استفاده شده است. همجنين از شبكههاى عصبى براى تخمين معكوس ماتريس زاكوبين استفاده شده است. در واقع براى تخمين هر يكك از سطرهاى ماتريس زاكوبين كه بيانكر نسبت تغييرات يكى از ويزگى هاى تصوير به تغييرات يكى از مفاصل هاى ربات است،

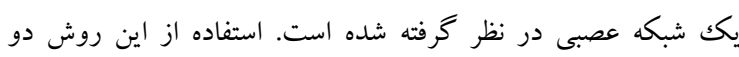
مشكل ذكر شده در استفاده از ماتريس زاكوبين را حل مى كند. البته اين روش به كنترل ربات در فضاى دو بعدى مى يردازد. علاوه بر آن روش

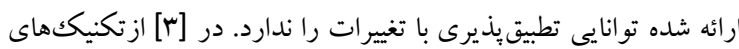
فازى براى تخمين مدل ربات-دوربين استفاده شده است. در اين مقاله ازكنترلگر فازى معكوس به منظور تخمين مدل معكوس ربات-دوربين براى محاسبه سرعت مفصل هاى ربات استفاده شده است. در مقاله مذكور با استفاده از يك دوربين كه مستقل از ربات نصب شده است، بازوى ربات را در يكك فضاى دو بعدى در مسير حلزونى شكل حركت داده موقعيت مجرىنهايى در هر كام حركتى ثبت مىشود. با استفاده از اين ويز گى ها و مقادير مفاصل ربات مدل فازى معكوس آموزش داده شده و

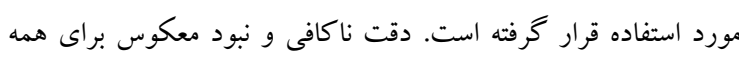
نقاط كار فر آيند ضعف اين دسته از روش ها است. گروهى از يُزوهشهاى صورت گرفته در زمينه كنترل بازوى ربات، از يادگيرى تقويتى استفاده كردهاند. از آنجا كه محيط كارى ربات كسترده است، نمىتوان حالات و عمل ها را به صورت مجزا مشخص لهر كرد. در يزوهشهاى [F، ه، 9، V] براى رفع اين مشكل به گُسته سازى فضاى حالت و عمل يرداخته است. حالات سيستم تقسيمبندىهاى فضاى كارى در قاب دوربين و عملها، يكك سرى عمل از ييش تعيين شده براى مفاصل ربات است. گسسته سازى همواره با مشكلاتى همراه است كه از جمله اين مشكلات مى توان به تنگناى ابعاد و عدم تضمين عملكرد بهينه اشاره كرد. در يزوهش [^] گسسته سازى در فضاى حالت و عمل صورت نكرفته و از شبكه عصبى براى تخمين تابع ارزش حالت عمل استفاده شده

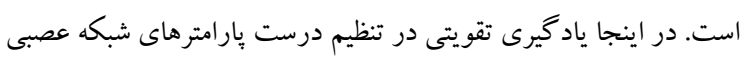

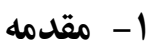

كنترل بينامبنا' عبارت است از استفاده از اطلاعات حسخرهاى بصرى براى كنترل ربات. اين اطلاعات مى تواند شامل نقاطى ازتصوير،خططها و يا ناحيه خاصى از تصوير باشند [1]. از جمله حسگرهايى كه در اين زمينه از آن استفاده مى شود دوربين است كه علاوه بر اينكه اطلاعات زيادى در اختيار كنترل گر قرار مىدهد، از نظر اقتصادى نيز مقرون به صرفه است

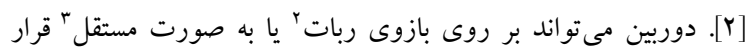
گيرد [1]]. كنترل بينامينا به سه گروه تقسيمبندى مىشوند [1]

$$
\text { روشهاى مبتنى بر موقعيت" روشهاى مبتنى بر تصويره }
$$

در روشهاى مبتنى بر موقعيت، از تصوير به دست آمده براى تخمين مختصات سهبعدى هدف موردنظر نسبت به دوربين يا يكك صفحه مختصات جهانى استفاده مىشود. بنابر اين نياز به مدل محيط و اطلاعات دقيق از ديناميك ربات و همجنين مشخصات دوربين است. در روشهاى مبتنى بر تصوير، تلاش بر اين است كه خطاى بين تصوير فعلى و تصوير

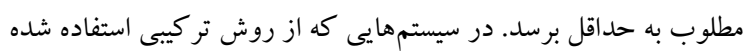
است، از تركيبى از دو روش قبل استفاده شده است. در اين روش برخلاف روشهاى مبتنى بر موقعيت نيازى به مدل محيط نيست و همخر ايى را برخلاف روش هاى مبتنى بر تصوير ضمانت مى كند. در اين مقاله تمركز بر روى كنترل با استفاده از روشهاى مبتنى بر تصوير است. در روشهاى سنتى كنترل مبتى بر تصوير نياز به دانستن مدل ربات-دوربين، رابطه بين ويزگگهاى تصوير و سينماتيك ربات، است. با استفاده از اين اطلاعات در هر مرحله از فر آيند كنترل ماتريس

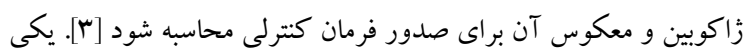

\footnotetext{
' Visual Servoing

r Eye-in-Hand

${ }^{r}$ Eye-to-Hand

${ }^{\dagger}$ Position-Based Visual Servoing

${ }^{\Delta}$ Image-Based Visual Servoing

४ $21 \frac{1}{2}$ D Visual Servoing
} 
تقويتى و انواع آن مى يردازيم. در ادامه معمارى عملكر -نقاد و يادگيرى تقويتى در فضاى بيوسته بيان مىشود. ז-1 مدلسازى فازى

مدلسازى فازى روشى براى نمايش دانش خبره به صورت زبانى و با استفاده از مجموعه اى از قواعد اخر -آنغاه است كه اين قوانين ساختار مدل را ايجاد مى كنند. يكك مدل فازى مى تواند از ابتدا و با استفاده از داده طر احى شود. به عبارت ديخر مدل فازى نقش يكك تقريب زننده جامع را براى سيستم ايفا مى كند. قضيه تقريب زنندگى جامع سيستم فازى بيان مى كند كه براى يكك سيستم ناشناخته (x) ييوسته باشد، مى توان با جمع آورى دادهها يكك سيستم فازى شامل قو اعد

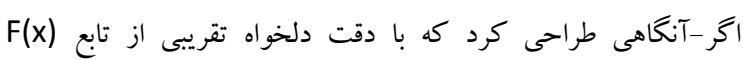

باشد] آن

دو مدل مشهور فازى عبار تند از[1 [I]:

$$
\text { مدل مدل فازى ممدانى' مازى سونوr }
$$

در اين مقاله از مدل فازى سو گنو مرتبه صفر استفاده شده است. در اين مدل فازى، ساختار قواعد به صورت زير است[ז]. مرتبه اين مدل فازى معادل سيستم فازى استاندارد است كه حالت خاصى از سيستمهاى ممدانى است.

$R_{i}=$ If $x_{1}$ is $A_{i 1}$ and $\ldots x_{n}$ is $A_{\text {in }}$ then $y_{i}$

$$
=b_{i} \quad i=1,2, \ldots, k
$$

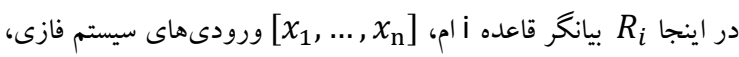
مجموعهاى فازى در نظر گفته شده براى مقادير ورودى، و $y_{i}$ خروجى هر قاعده است. خروجى سيستم فازى از رابطه

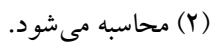

$$
\begin{gathered}
\hat{y}=\frac{\sum_{i=1}^{K} \beta_{i} y_{i}}{\sum_{i=1}^{K} \beta_{i}} \\
: \text { كه در اينجا } \beta_{i}=\prod_{j=1}^{n} \mu_{A_{i j}}\left(x_{i}\right) i=1,2, \ldots, k
\end{gathered}
$$

كه [0,1]

$$
\text { فازى }
$$

نقش موثرى دارد. هرجند يادگيرى تقويتى دو قابليت ياد گيرى تنها با يكك معيار عددى راندمان و آموزش برخط را داراست، اما سرعت يادگيرى آن بايين است و نياز به تكرارهاى زياد آزمايش دارد.

در اين مقاله يك كنترلخر فازى تركيبى ارائه مىشود. در اين كنترلكر از كنترل ييرامون هدف استفاده مى شود و يك كنترل گر خبره فازى براى رساندن دقيق مجرى نهاى به هدف بكار گرفته شده است. سبس بِارامترهاى اين كنترل گر خبره فازى به منظور بهبود كارايى و تطبيقيذيرى با تغييرات جزئى با روش يادگيرى تقو يتى تنظيم مىشوند. در اينجا از كينكت' [9] بعنوان حسگر بصرى براى استخراج ويزگى هاى سهبعدى و اطلاعت عمق بهره برده مى شود. مزيت استفاده از كينكت اين است كه علاوه بر اطلاعات تصوير RGB، اطلاعات عمق را نيز در اختيار قرار مىدهد و نيازى به استفاده از جند دوربين براى استخراج اطلاعات عمق، كه خود نياز به دانستن بارامترهاى داخلى و خارجى دوربينها است، نمىباشد. روش ارائه شده بر روى بازوى ربات

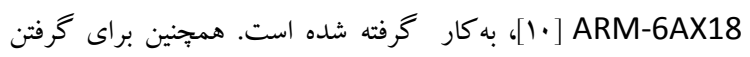

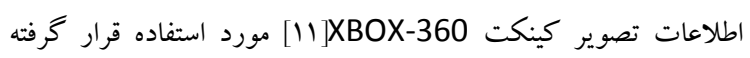
است. دوربين جدا از ربات و به صورت مستقل نصب شده است. به طور كلى سهم علمى اين تحقيق شامل موارد زير است:

ارائه ساختار كنترل گر تر كيبى فازى براى حل مسئله كنترل بازوى ربات به صورت تركيبى از كنترلگر

$$
\text { معكوس فازى و كنترل گر خبره فازى. }
$$

ارائه راهكارى براى تنظيم برخط كنترل گر خبره فازى

$$
\text { با استفاده از يادگيرى تقويتى }
$$

حل جالشهاى به كارگيرى روشهاى فوق در يكك مسئله عملى و به كار گيرى آنها بر روى بازوى ربات

$$
\text { واقعى }
$$

ساختار مقاله به شرح زير است كه در بخش دوم مفاهيم پايه مى آيد. در بخش سوم روش ييشنهادى شرح داده مىشود. در بخش جهارم نتايج آزمايشات بر روى بازوى ربات ذكر شده است. در نهايت در بخش بنجم نتيجه گيرى و كارهاى آينده بيان شده است.

\section{r- مفاهيم يايه}

در اين بخش ابتدا به معرفى مدل سازى فازى، مدل معكوس فازى و

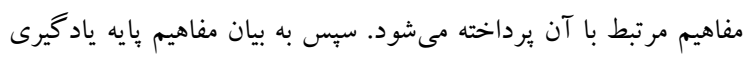

${ }^{r}$ Mamdani Fuzzy Model

${ }^{r}$ Takagi-Sugeno Fuzzy Model

' Kinect 


$$
U=G(x(k), x(k+1))
$$

به اين معنى كه عمل يكتايى مثل U وجود دارد كه حالت سيستم را از

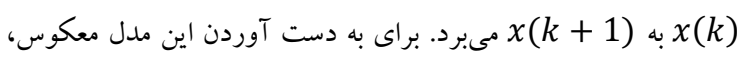

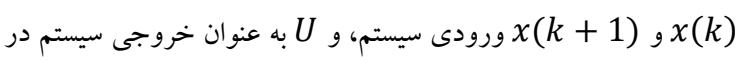
نظر گرفنه مىشود. سيستم فازى نهايى در نهايت معكوس فرآيند را تخمين مىزند.

\section{r-r ياد كيرى تقويتى}

يادگيرى تقويتى يكك روش يادگيرى بر خط مىباشد كه بصورت

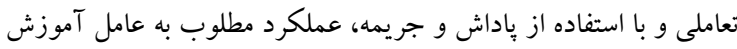
داده مىشود. اين باداش يا جريمه را سيخنال تقويتى مىنامند. به بيان ديخر يادگيرى از طريق حداكثر كردن سيكنال تقويتى كه مقدارى

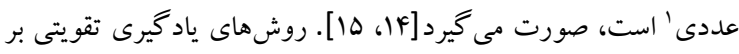
اساس نحوه تخمين تابع ارزش شكل گرفتهاند. متداولترين آنها روشهايى هستند كه از خطاى تفاضل موقتى ب استفاده مىنمايند.

\section{r-r ياد عيرى تفاضل موقتى}

سادهترين روش تفاضل موقتى ‘ كه آن را (0) TD مئنامند، براى

تخمين تابع ارزش حالت بصورت زير بكارمى رود [01، 19 ] :

$$
V\left(s_{t}\right) \leftarrow V\left(s_{t}\right)+\alpha_{t}\left[r_{t+1}+\gamma V\left(s_{t+1}\right)\right.
$$$$
\left.-V\left(s_{t}\right)\right]
$$

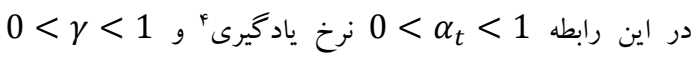
ضريب نزوله وr مقدار بِاداش آنى هستند. بيان كننده حالت سيستم در زمان t و $1+1$ و $V$ و مشخص كننده ارزش حالت است. در اين رابطه، عبارت داخل كروشه را خطاى تفاضل موقتى مى نامند. دو معمارى معروف استفاده شده براى كاربرد يادگيرى تقويتى

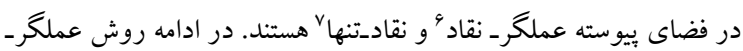
نقاد كه در اين مقاله از آن استفاده شده است، شرح داده مىشود.

'Scalar

${ }^{r}$ TD-Error

rTemporal Difference

${ }^{r}$ Learning Rate

${ }^{\diamond}$ Discount Factor

${ }^{4}$ Actor-Critic

${ }^{\vee}$ Critic-Only
قو اعد فازى را مى توان با استفاده از دادهها استخراج كرد. به عبارت ديخر اخر بردار X ورودى سيستم در هر مرحله و Y خروجى سيستم

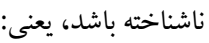

$$
X^{T}=\left[x_{1}, \ldots, x_{p}\right], \quad y^{T}=\left[y_{1}, \ldots, y_{n}\right]
$$

همانطور كه در مقالات مختلف از جمله [با] بيان شده است خوشه بندى يكى از راههاى شناخته شده در توليد قواعد فازى با استفاده از دادههاى ورودى خروجى است. اين روش دادهها را به گروههاى همگن تقسيم بندى مى كند و اين كار باعث مى شود كه دادهاى مشابه كه رفتار مشابهى در سيستم دارند در يكك گروه قرار گرفته و كل خوشه حاصل، نماينده آن دادهها باشد. سپبس براى اين گروه از دادهها قاعده ایى در نظر كرفته خواهد شد. دراين مقاله براى ساخت مدل فازى از جعبه ابزار فازى C- متلب و دستور genfis3 استفاده شده است. اين دستور از فازى means براى خوشهبندى دادهها و توليد قو اعد فازى استفاده مى شود.

\section{r-r مدل معكوس}

براى به دست آوردن مدل معكوس و تخمين تابع $f^{-1} f^{-1}$ مى موان از

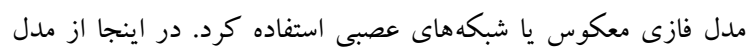
فازى معكوس استفاده شده است كه با استفاده از داده جمع شده ساخته مىشود. به اين صورت كه اكر تمام حالات فرآيند مشخص باشد، داريم[V]

$$
x(k+1)=f(x(k), u(k))
$$

كه (k+1) فرآيند در زمان k و $2(k)$ فرمان كنترلى در زمان k است. بنابراين

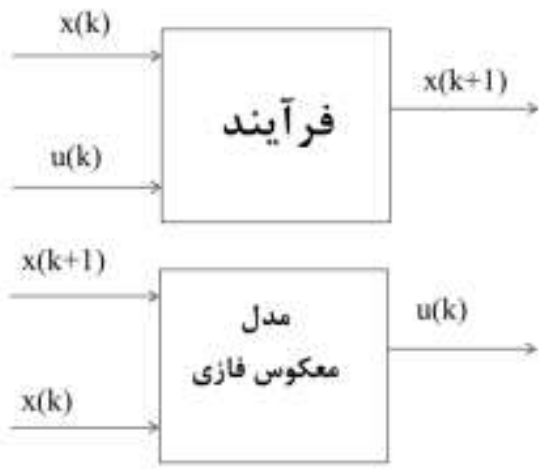

شكل ا: فرآيند و مدل فازى معكوس آن معادله ديناميكى معكوس اين فر آيند به صورت (و) است: 


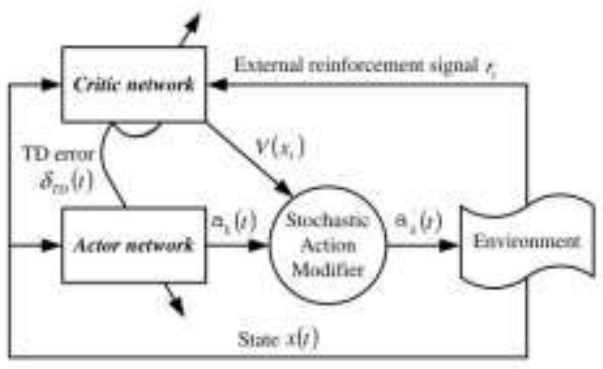

شكل Y:معمارى يكك سيستم كنترلى IV] FACRLN

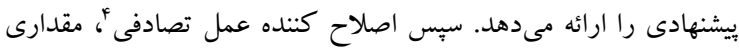
تصادفى با توجه به ميزان ارزش آن توليد كرده و با اضافه كردن آن به عمل انتخابى، عمل واقعى را توليد مى كند. شبكه نقاد سيخنال تقويتى را دريافت كرده و خطاى تفاضل موقت (t) شكل ع اين شبكه را نمايش مى دهد. از آنجايى كه دو شبكه نقاد و عملكر ورودى يكسانى دارند و فقط در خروجى داراى تفاوت هستند، لايه هاى يكك تا سه براى آنها مشتركك است. در ادامه به توضيح هر كدام از اين لايه ها مى بردازيم. لايه اول همان لايه ورودى است كه بردار ورودى را دريافت مى كند و به لايه بعد ارسال مى كند. لايه دوم لايه قواعد است كه هر واحد آن قسمت مقدم يكى از قواعد را با n تابع عضويت گگسى شكل نشان مىدهد. خروجى اين لايه شدت آتش هر قاعده است كه از رابطه (ᄉ) به دست مى آيد.

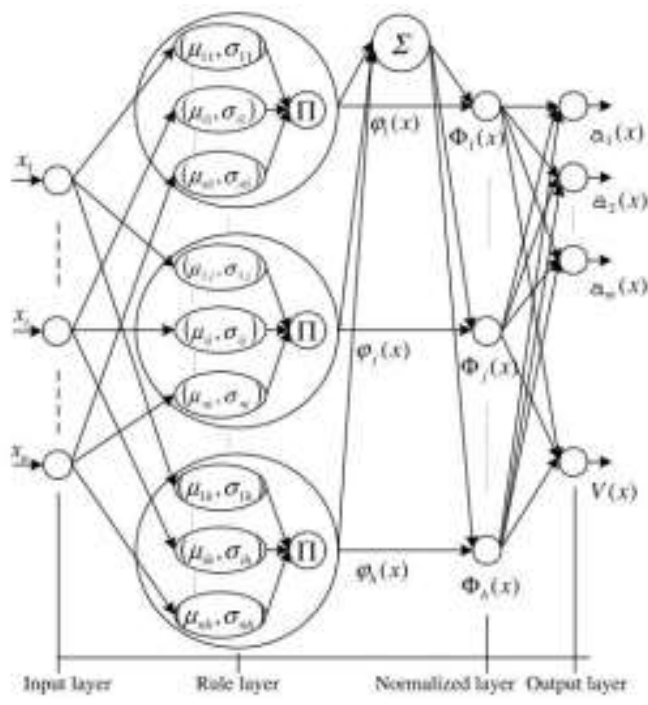

[iv] FACRLN شكل f: يكك شبكه r-0 روش عملكر -نقاد

روش عملكر -نقاد از جمله روش هاى يادگيرى تفاضل موقتى است كه ساختارى مستقل از تابع ارزش براى بيان سياست گذارى دارد. اين

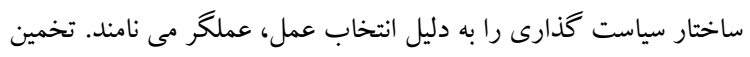
زننده تابع ارزش كه نقش نقدكننده عمل صورت گرفته را بر عهده دارد را، نقاد مى گو يند. يادگيرى در اين روش به صورت برسياست' است.

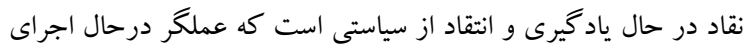
آن است. انتقاد به فرم خطاى تفاضل موقتَ براى يادگيرى عملكر و نقاد

استفاده مىشود. شكل ب اين فر آيند را نشان مىدهد [10].

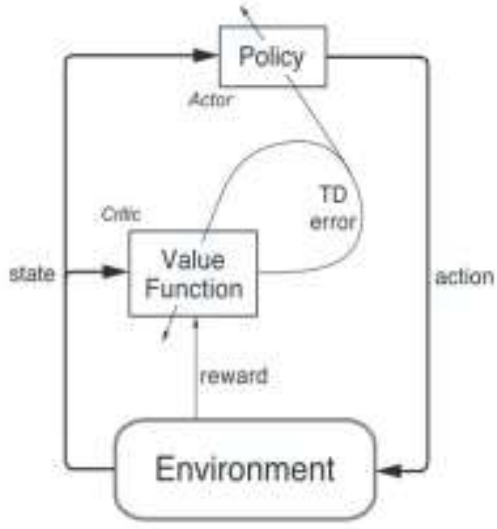

شكل ז'معمارى عملكر -نقاد [II]

r-7 شبكه يادكيرى عملكر -نقاد فازى

در [IV] ثابت شده است كه سيستم استنتاج فازى در واقع يكك تقريب زننده است كه مى تواند هر مجموعه داد ورودى-خروجى را تقريب زند. يكك سيستم فازى دانش بشر را به كونه ای قابل فهم كد مى

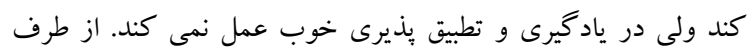
ديخر شبكه هاى عصبى توانايى ياد گيرى و تحمل خطا را دارند ولى براى نمايش دانش مناسب نيستند. بنابراين مى توان از خصوصيات هر دو اين ئ ئرس تقريب زننده ها استفاده كرد. با توجه به مطالب ذكر شده، شبكه هاى ياد گيرى عملكر -نقاد فازى را كه از اين به بعد به اختصار آنها را FACRLN" مى ناميم، معرفى

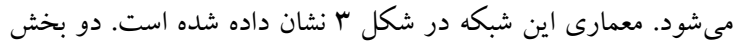
مهم اين معمارى شبكه نقاد و عملگر هستند. شبكه عملكر، نگاشت بين حالت-عمل را ياد مى گيرد و شبكه نقاد، تابع ارزش سياست دنبال شده،

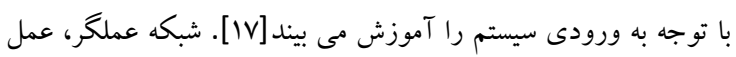

${ }^{3}$ Fuzzy Actor-Critic Reinforcement Learning Network 
مى آيد، حر كت مفاصل ديخر از طريق يكك موتور صورت مى گيرد. نحوه صدور فرمان به موتورهاى اين ربات از طريق تعيين زاويه جرخش آنها است. همجنين اين امكان فراهم شده است كه در صورت لزوم بتوان زواياى هر يكك از موتورها را از طريق بازخوردى كه مورتوها به ما مىدهند، به دست آورد. هدف از طراحى اين كنترلگر، رساندن مجرى نهايى بازوى ربات، از هر نقطه شروع اوليهاى به نقطه هدف تعيين شده در محدوده كارى ربات است. به منظور كنترل بازو از يكك كنترل فازى استفاده شده است كه شامل كنترل گر معكوس فازى و كنترل خبره فازى است. كنترل گر تر كيبى در حالتى كه محيط بدون تغيير باشد، يعنى ربات و دوربين جاى ثابتى داشته باشند، كارايى دارد. در صورت ايجاد تغيير در محيط ديخر اين كنترل تعيين دقيق بارامترهاى كنترل گر خبره فازى امكان بذير نيست و ضعف هايى دارد. لذا از يادگيرى تقويتى به منظور يادگيرى تغييرات به صورت برخط و برطرف كردن ضعفهاى كنترلگر خبره فازى استفاده شده

\section{r-1 كنترل}

براى طراحى كنترل گر تركيبى فازى از دو كنترل گر استفاده شده است. كنترلگر اول نقش رساندن مجرى نهايى به محدوده نزديك هدف را به عهده دارد و يكك كنترل گر معكوس فازى است. كنترل

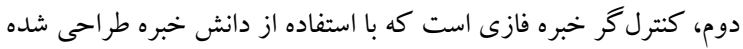

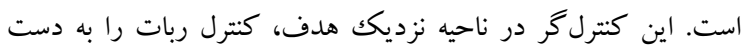

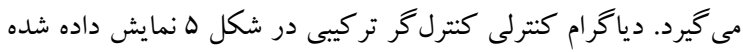

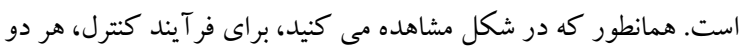
كنترل گر مختصات مجرى نهايى در تصوير احتياج دارند. با توجه به به اينكه دئه در اينجا هدف كنترل بازو در فضاى سه بعدى است، علاوه بر مختصات

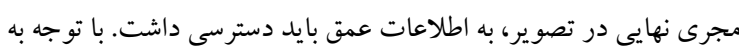
اين خاصيت كينكت كه هر دو تصوير RGB و عمق را در فراهم مى كند،

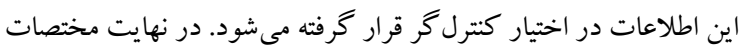

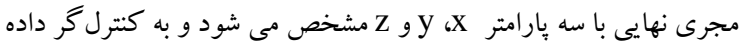

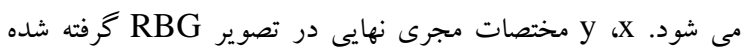

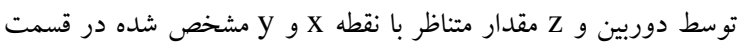
قبل، در تصوير عمق گرفته شده از كينكت است. علاوه بر اين كنترل فازى معكوس سه ورودى ديخر دارد كه همان مقادير زاويه موتورها هستند. مقادير مو تورها در واقع مشخص كننده وروى دالت فعلى سيستم هستند. r-1-1 كنترل

$$
\varphi_{j}\left(x_{t}\right)=\exp \left(-\sum_{i=1}^{n} \frac{\left(x_{i t}-\mu_{i j}\right)^{2}}{2 \sigma_{i j}^{2}}\right)
$$

كه ب و م ميانگين و انحر اف معيار هر كدام از توابع عضويت هستند و X برابر با iامين متغيير ورودى بردار t $x_{t}$ است. لايه سوم خروجى لايه دوم را نرمالسازى مى كند و لايه جهارم خروجى شبكه عملكر و نقاد است. خروجى نقاد حاصل تخمينى از ارزش حالت است. به عبارت

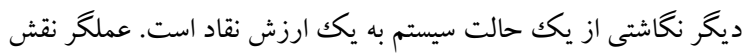
يكك انتخاب كننده عمل را اجرا مى كند كه نكاشتى از آنجه سيستم از فضاى n بعدى درك مى كند به فضاى m بعدى عمل ها است. خروجى عملكر و نقاد (X) لعاد به صورت زير محاسبه مى شود:

$$
\begin{array}{r}
a_{i}\left(x_{t}\right)=\sum_{j=1}^{h} w_{i j} \Phi_{j}\left(x_{t}\right) \quad i= \\
V\left(x_{t}\right)=\sum_{j=1}^{h} v_{j} \Phi_{j}\left(x_{t}\right)
\end{array}
$$

در (q)، (x) وزنهاى بين خروجى نرمال شده قاعده زام و خروجى عملكر أم مىباشد. در (•)، إ) وزن بين خروجى نرمال شده قاعده زام و بخش نقاد است. به منظور داشتن كاوش در محيط عمل محاسبه شده به طور مستقيم در

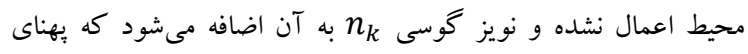
كوسى رابطه عكس با ارزش حالت فعلى ربات دارد. (x) محاسبه شده بعد از اضافه كردن نويز به عمل محاسبه شده است.

$$
a_{i}^{\prime}\left(x_{t}\right)=a_{i}\left(x_{t}\right)+n\left(0, \sigma_{v}(t)\right)
$$

$$
\sigma_{v}(t)=\frac{1}{1+\exp \left(2 V\left(x_{t}\right)\right)}
$$

يك $n\left(0, \sigma_{v}(t)\right)$ و انحراف معيار (t $\sigma_{v}$ توليد مى كند كه به عمل محاسبه شده اضافه مىشود. اخر مقدار V(xt)، يعنى ارزش حالت كوخهك باشد مقدار كاوش زياد است و بالعكس.

\section{r- - روش ارائه شده}

در اين فصل، به معرفى روش ارائه شده براى كنترل بازوى ربات با سه درجه آزادى مى يردازيم. اين ربات داراى سه مفصل پايه، شانه و

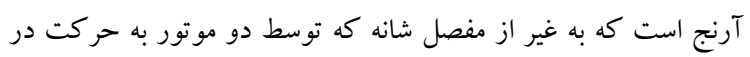




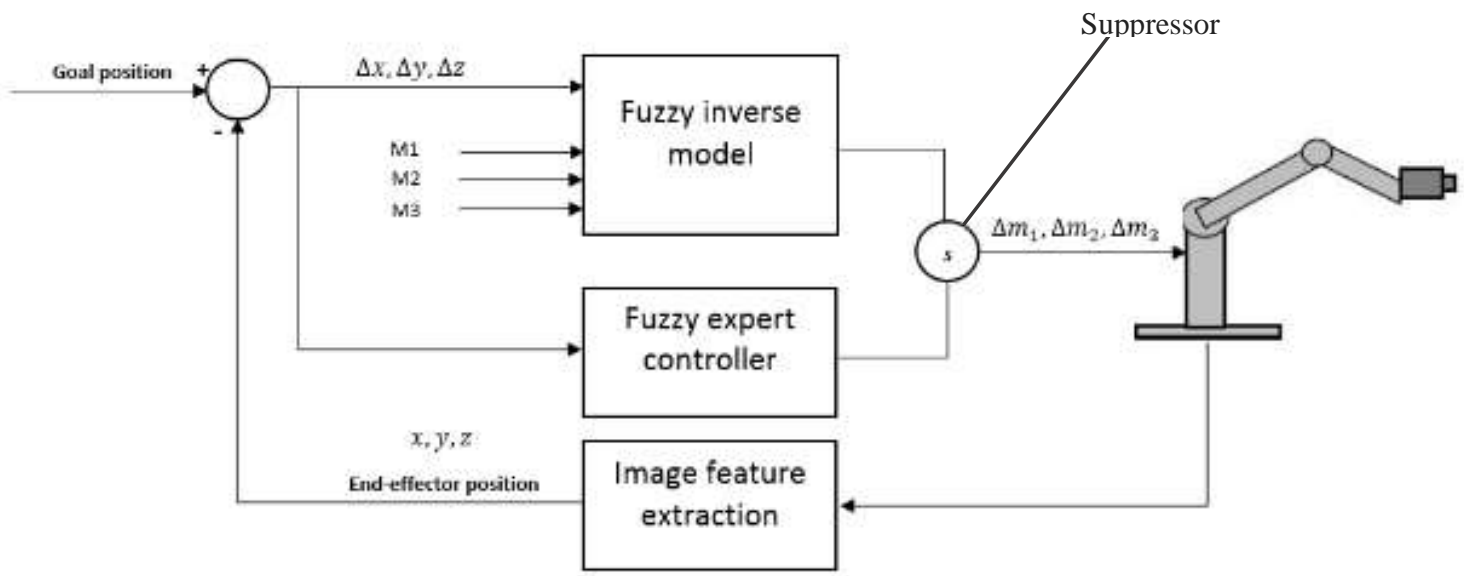

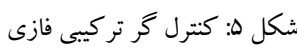

[19611] دو روش رايج براى اين كار جدول مراجعه' و خوشهبندى

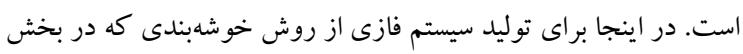
قبل به آن اشاره شد استفاده شده است. از آنجا كه حجم دادههاى جمع آورى شده از محيط زياد بود، امكان توليد قواعد به صورت دستى و استفاده از تقسيم بندى مشبك و روشهاى ديخر نبود. براساس آنجه در [r.r] آمده است خوشهبندى يكى از روشهاى مرسوم در كاهش حجم

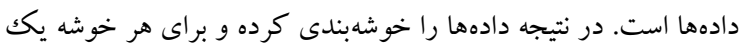
قاعده فازى در نظر گر فته شده است. آزمايشات اوليه نشان داد، زمانى كه تهات تنها از كنترل كر معكوس فازى استفاده مى شود دقت لازم را ندارد. نتايج

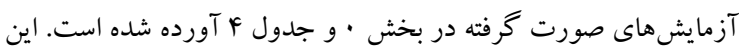
عدم دقت به دليل معكوسيذير نبودن سيستم در برخى نقاط و همجنين

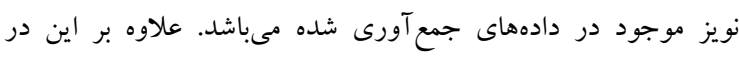

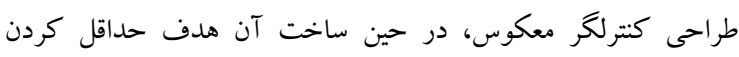

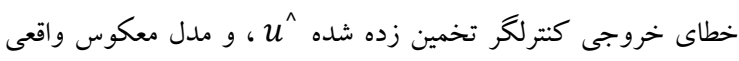
يعنى U است. در حالى كه در عمل و استفاده از اين مدل، هدف حداقل كردن فاصله مجرى نهايى ^y و هدف y است. با توجه به آنجه كفته شد و به دليل حساسيت ... ٪ كنترل كننده معكوس به خطاى مدل سازى، اين كنترل كنده به تنهايى براى كنترل دقيق بازوى ربات كارايى ندارد. به

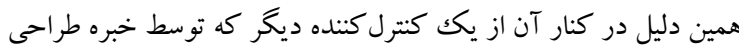
شده، استفاده شده است. وجود كنترل كننده معكوس فازى باعث مى شود كه فضاى عملكرد كنترل كنده خبره تنها محدود به نقاط اطراف نقطه كار شده و درنتيجه ساختار و طراحى آن توسط خبره با مشاهده عملكرد واقعى سيستم سادهتر گردد. لذا به منظور كنترل نهايى، كنترلخر

' Table Look-Up
كنترل كر معكوس فازى نهايى يك سيستم فازى سو كنو مرتبه صفر

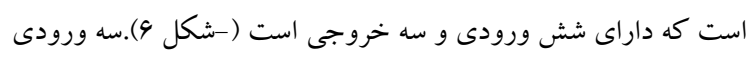
[ فاصله مجرى نهايى از هدف در تصاوير RG, $[\nabla y, \nabla z]$ است. سه ورودى ديخر يعنى [m1,m2,m3] مقادير سه موتور مفاصل ربات هستند كه بيان كنده وضعيت فعلى ربات است. همانطور كه قبل تر به آن اشاره شد، يكى از راههاى طراحى يك سيستم فازى،

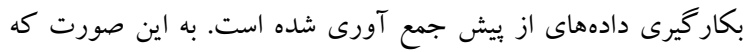
ورودى و خروجى هاى يكك فر آيند را مشاهده، و ذخيره كرده و از آنها در تخمين تابعى كه تقريبى از معكوس فرآيند اصلى باشد، استفاده

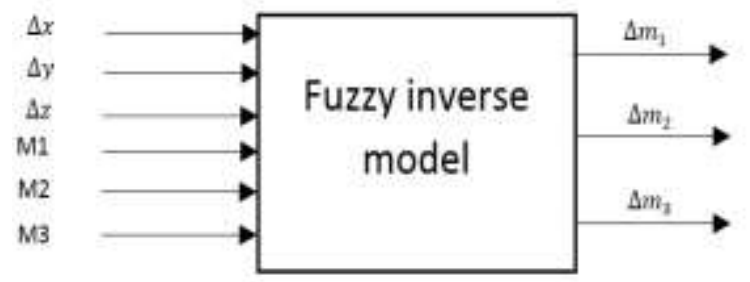

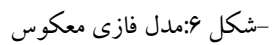

راى جمع آورى اطلاعات در اين مورد خاص ربات را در موقعيت متفاوت نسبت به مبدأ آن قرار مىدهيم و مختصات مجرى نهايى و مقادير

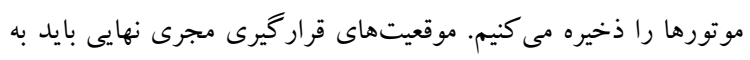

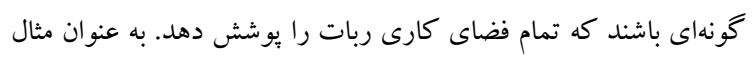

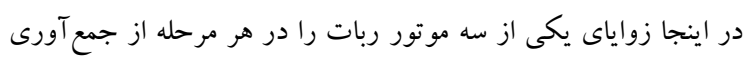

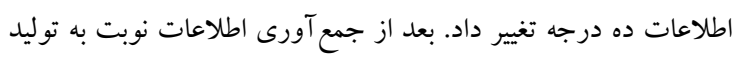

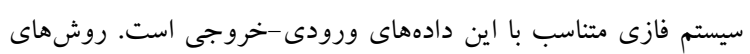
مختلفى براى توليد سيستم فازى از روى اين دادها وجود دارد. بر اساس 
سيستم فازى كه به عنوان كنترل كر خبره فازى در بخش r-I-Y معرفى كرديم رابه صورت دانش اوليه در نظر مى گيريم. در شكل F هر كدام از واحدهاى لايه قواعد يكى از قواعد كنترلكر خبره فازى را نمايش مىدهند. همجنين وزنهايى كه از لايه سوم خارج شده و وارد بخش عملكر لايه جهارم مىشود، به همان خروجى هاى كنترل گر خبره فازى مقداردهى شده است. آنجه در حين فرآيند آموزش تغيير مى كند، وزنهاى خارج شده از لايه سوم شبكه به لايه جهارم براى هر دو بخش نقاد و عملكر است. اين نكته قابل توجه است كه اين شبكه جايكزين كنترلگر خبره فازى مىشود و فقط در نواحى نزديكك هدف مورد استفاده قرار مى گيرد. فر آيند آموزش در اين روش به اين صورت است كه ابتدا موقعيت مجرى نهايى و فاصله آن با هدف را توسط دوربين كينكت به دست آورده و فرمان كنترلى صادر مىشود. اكر فرمان صادر شده مناسب بود، يعنى فاصله مجرى نهايى تا هدف كم شده باشد، سيستم پياداش مى گيرد و در غير اين صورت جريمه مى شود. بعد از محاسبه عمل و مقدار ارزش

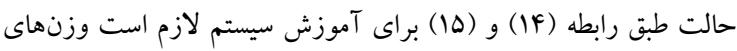
بخش نقاد و عملكر بروزرسانى شود. به منظور محاسبه ميزان بروزرسانى

وزن ها ابتدا بايد خطاى تفاضل موقتى بمحاسبه شود [If].

$$
\delta_{T D}(t)=r_{t}+\gamma V\left(x_{t+1}\right)-V\left(x_{t}\right)
$$

t+1 g t مشخص كننده حالت سيستم در زمانهاى $x_{\mathrm{t}+1}, x_{t}$

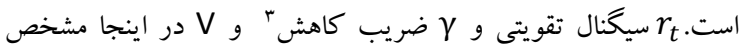
كننده ارزش هر حالت است. خطاى تفاضل موقتى اخر مثبت باشد نشاندهنده اين است كه حالت فعلى با توجه به عمل انجام شده بهتر از حالت قبلى بوده و اگر منفى باشد بالعكس. از اين خطاى تفاضل موقت براى به روز رسانى وزنهاى بخش عملكر و نقاد استفاده مىشود. وزنهاى بخش عملكر به صورت زير بروزرسانى مىشوند: $w_{i j}(t+1)$

$$
\begin{gathered}
=w_{i j}(t) \alpha_{A} \delta_{T D}(t) \frac{a^{\prime}{ }_{i}\left(x_{t}\right)-a_{i}\left(x_{t}\right)}{\sigma_{v}(t)} \Phi_{j}\left(x_{t}\right) \\
v_{i}(t+1)=v_{i}(t) \alpha_{c} \delta_{T D}(t) \Phi_{j}\left(x_{t}\right)
\end{gathered}
$$

معكوس، مجرى نهايى را به نواحى اطراف هدف رسانده و در نواحى نزديك هدف از كنترل كر فازى خبره، استفاده شده است.

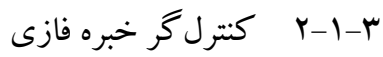
كنترل گر خبره فازى توسط خبره و با توجه به مشاهدات صورت گرفته در نحوه عملكرد ربات در محيط طراحى شده است. اين كنترل گر هم از نوع سو گنو مرتبه صفر است و همانند كنترلگر معكوس فازى، داراى سه ورودى است. ورودى ها به ترتيب بيانكنده فاصله مجرى

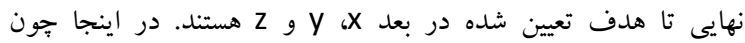
كنترلگر در فضاى محدودى مورد استفاده قرار مى گيرد، بدون نياز به حالت سيستم و مقادير مو تو رها هم عملكرد سيستم قابل قبول است. لذا به منظور كاهش يِيجيدگى از آنها استفاده نشده است. خروجى نيز ماند كنترل مفاصل است. اين كنترل گر زمانى كه مجرى نهايى در محدوده نزديك مكري هدف قرار مى گيرد، خروجى كنترل گر معكوس فازى راغيرفعال كرده و خود، كنترل ربات را بر عهده مى گيرد. محدوده نزديكك عبارت است از ناحيه ایى اطراف هدف، كه از قبل تعيين شده است. r-r تنظيم بر خط كنترل اكر در محيط تغييرى ايجاد شود، مثلا ربات نسبت به دوربين جابجا شود، و يا زاويه دوربين تغيير كند، ديخر كنترلگر تر كيبى دقت مناسب را ندارد. علاوه بر آن به دليل طراحى كنترل گر خبره فازى توسط دانش خبره، و تنظيم نبودن دقيق پارامترهاى آن، اين كنترلكر داراى ضعفهايى از جمله حر كات نوسانى اطراف هدف مىباشد. روشهاى مختلفى همجون مجموع مربعات خطا تكرارشونده' و يادگيرى تقويتى براى تنظيم پارامترهاى كنترل گر وجود دارد. در اين بُزوهش، از معمارى

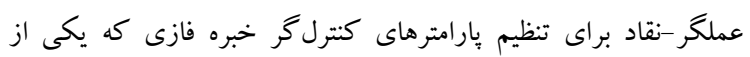
روش هاى يادگيرى تقويتى فازى است، استفاده شده است. نكته قابل توجه ديخر آن اين است كه هرجند محيط عملكرد كوجّك باشد، با اين حال با توجه به اينكه يادگيرى تقويتى از اطلاعات كمى استفاده مى كند و تنها معيار ياد گيرى يكك مقدار عددى است، زمان آموزش طولانى دارد. مورد ديخر اينكه زمانى كه فر آيند آموزش طولانى باشد در عمل باعث داغ شدن موتورهاى ربات شده و آزمايشات عملى را با مشكلاتى همراه خواهد كرد. لذا در اين يزوهش به منظور افزايش سرعت ياد گيرى، دانش اوليه به سيستم تزريق مى كنيم. بدين صورت كه

' Recursive Least Square Error
${ }^{r}$ Temporal Diffrence

${ }^{r}$ Discount Factor 
هايى در آزمايشات استفاده شده است، 10BOX-360] است. محل قرارگيرى كينكت در بشت سر ربات و در جايى ثابت در محيط

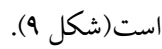

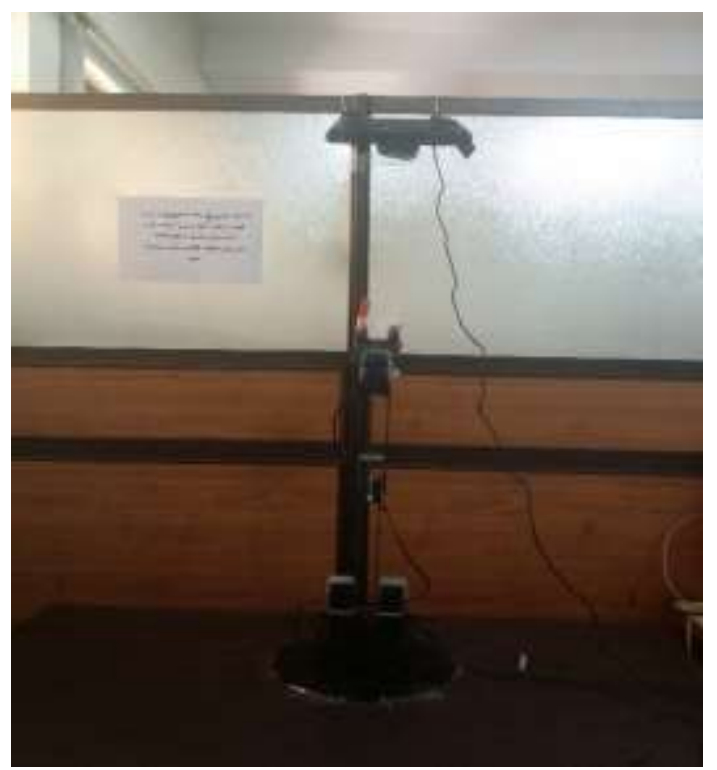

شكل 9: نحوه قرار كيرى كينكت نسبت به ربات

جدول ا:مشخصات موتورهاى ربات

\begin{tabular}{|c|c|c|c|c|c|c|}
\hline موتور & موتور & زراويه & رركت & موتو & مفص & موتو \\
\hline Q ז, & 1 & $r .$. & افقى & 1 & $\begin{array}{c}\text { AX- } \\
18\end{array}$ & צايه \\
\hline Q ז, & r.r & 11. & عى عمد & r & $\begin{array}{l}\text { AX- } \\
18\end{array}$ & شانه \\
\hline $\begin{array}{l}\cdots \wedge \\
\wedge\end{array}$ & F & $r .$. & عمود & 1 & $\begin{array}{c}\text { MX- } \\
28\end{array}$ & آرنج \\
\hline
\end{tabular}

\section{ع-1 جمع آورى داده براى كنترلكر معكوس فازى و}

\section{طراحى آن آن آن}

به منظور جمع آورى اطلاعات بايد ربات را در موقعيت هاى مختلف در محيط كارى آن قرار داد و اطلاعات مربوطه موقعيت مجرى نهايى و مقادير موتورها را جمع آورى كرد. در اين مقاله موقعيت مجرى نهايى و مقادير موتورها با تغيير ينج درجه در مقادير موتورها در هر مرحله از جمع آورى اطلاعات ذخيره شده است. اين فرآيند تا زمانى كه كل ناحيه در دسترس ربات ييموده شود ادامه داده مى شود. براى مشخص كردن مجرى نهايى در تصوير و به دست آوردن مختصات آن، يكى از گيره

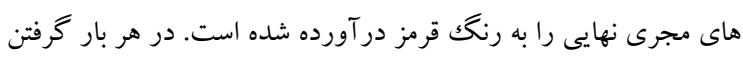

در روابط (14) و (15) (x)

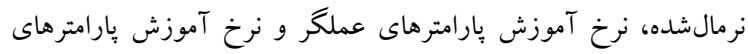

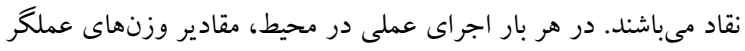
و نقاد بروزرسانى مى شوند. در ياد خيرى تقويتى هدف حداكثر كردن ياداش در بلند مدت است و با توجه به آنجه گكته شد، در تكرارهاى متوالى سيستم به سمتى ييش مى رود كه به حداكثر باداش كه همان

$$
\text { رسيدن به هدف با كمترين زمان است، برسد. }
$$

\section{ع- ع آزمايشها}

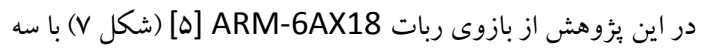

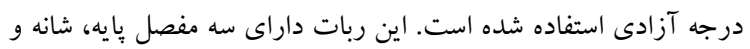

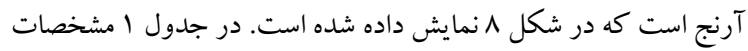

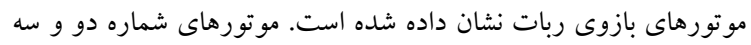

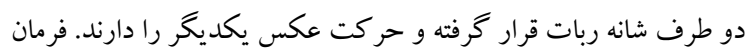

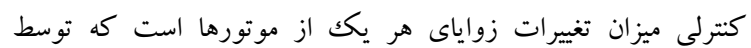
كنترل گر صادر شده و به آن اعمال مى شود.
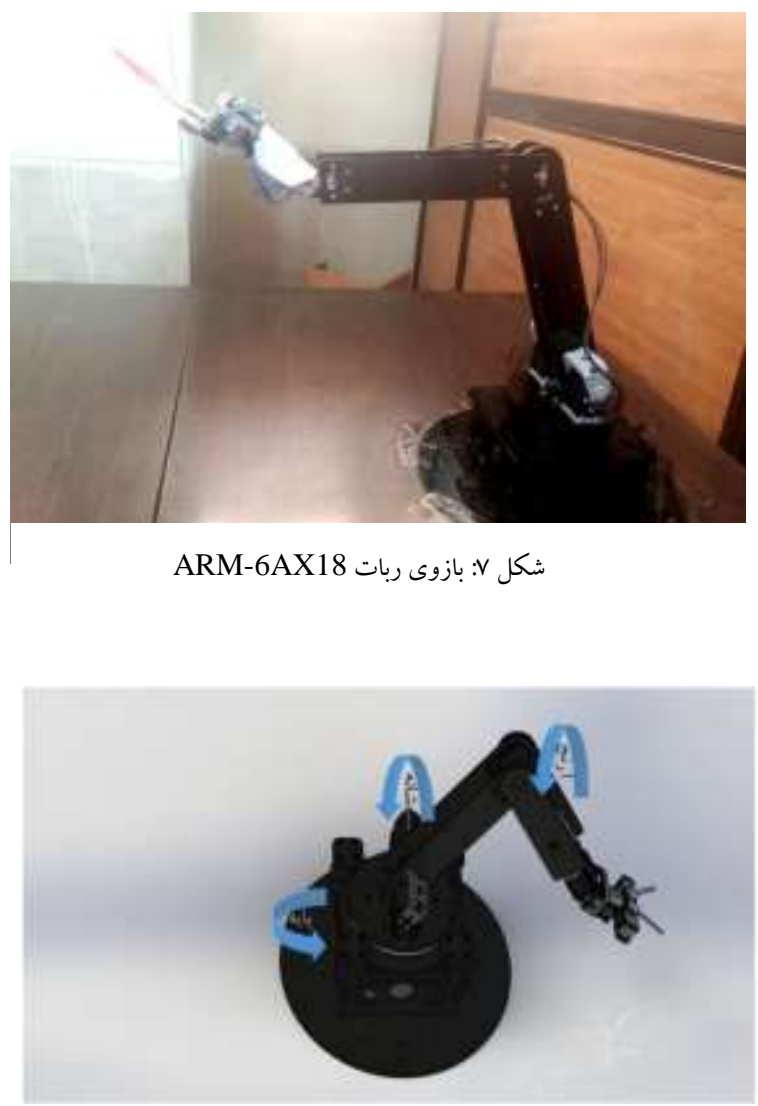

شكل م: مفاصل ربات

در ادامه به توضيح نحوه جمع آورى اطلاعات براى ساخت كنترل گر

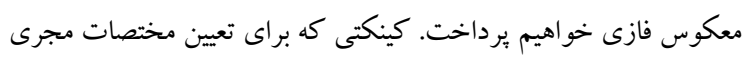


مجرى نهايى در محدوده $100<-100<-100$ - 100 Dy< 100

باشد.

\section{ع-r طراحى كنترل}

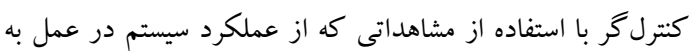
دست آمده، طراحى شده است. اين كنترل گر يكك سيستم فازى سو كنو

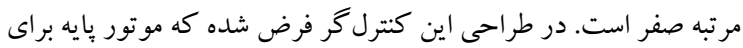
رساندن مجرى نهايى در بعد، X موتورهاى شانه در بعد ل و موتور آرنج

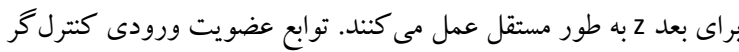
خبره فازى طراحى شده در شكل ل| 11 نمايش داده شده است.

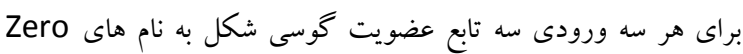

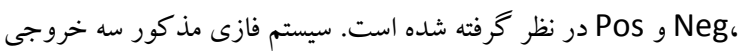
دارد كه هر كدام مشخص كننده تغييرات در زواياى هر كدام از مفصلهاى ربات است. خروجى هاى اين سيستم براى موتور بايه داراى

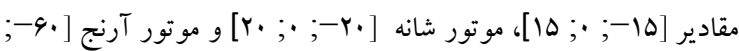
·; · · هستند. براى اين سيستم rV قاعده نوشته شده است. برخى قو اعد كنترل گر خبره فازى در جدول r نشان داده شده است.

\section{ع-1 نتايج آزمايش كنترل}

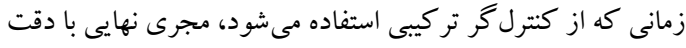

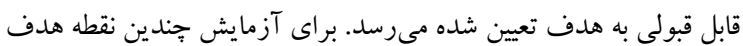
در محيط كارى ربات در نظر گرفته شده است. با استفاده از كنترل

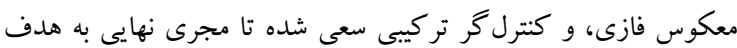
تعيين شده برسد.
تصوير توسط كينكت نقاط قرمز رنگك را در تصوير RGB بيدا كرده و مركز آنها را به عنوان مختصات فعلى مجرى نهايى در نظر گرفته مىشود. سِّ نقطه متناظر با اين نقطه را، در تصوير عمق را به عنوان عمق مجرى لرى نهايى در نظر گرفته مىشود. بِ از جمع آورى اطلاعات نوبت به طراحى مدل فازى معكوس مىرسد. ورودى-خروجى هاى مدل همان جيزى است كه در -شكل 9 نشان داده شده است. از آنجايى كه مقادير موتورهاى شانه مكمل هم هستند، تنها يكى از آنها در طراحى مدل استفاده شده است. براى مقدار m3 هم زاويه موتور آرنج در نظر گرفته شده است. براى ساخت مدل فازى از جعبه ابزار فازى متلب استفاده شده است. دستور genfis3 مجموعه داده هاى ورودى و خروجى را به صورت جداكانه دريافت مى كند. علاوه بر آن نوع سيستم فازى كه در اينجا "Sugeno" است را دريافت مى كند. خروجى اين تابع يك سيستم فازى سو گنو مرتبه صفر است كه همان مدل فازى معكوس است كه با استفاده از خوشهبندى دادهها به وجود آمده است. شكل · ا توابع عضويت سه ورودى كنترل گر فازى معكوس كه مربوط به مقادير مجرى نهايى در سه بعد، بعد از خوشه بندى را نشان مىدهد. هم:خنين جدول r برخى قواعد فازى توليد شده توسط دستور genfis3 را نشان مىدهد. كفته شد كه در آزمايشهاى عملى كنترل گر معكوس به تنهايى دقت

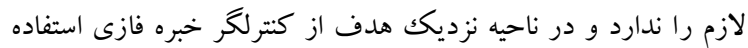

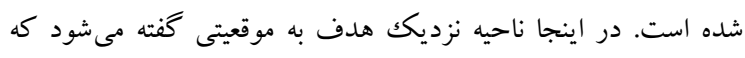
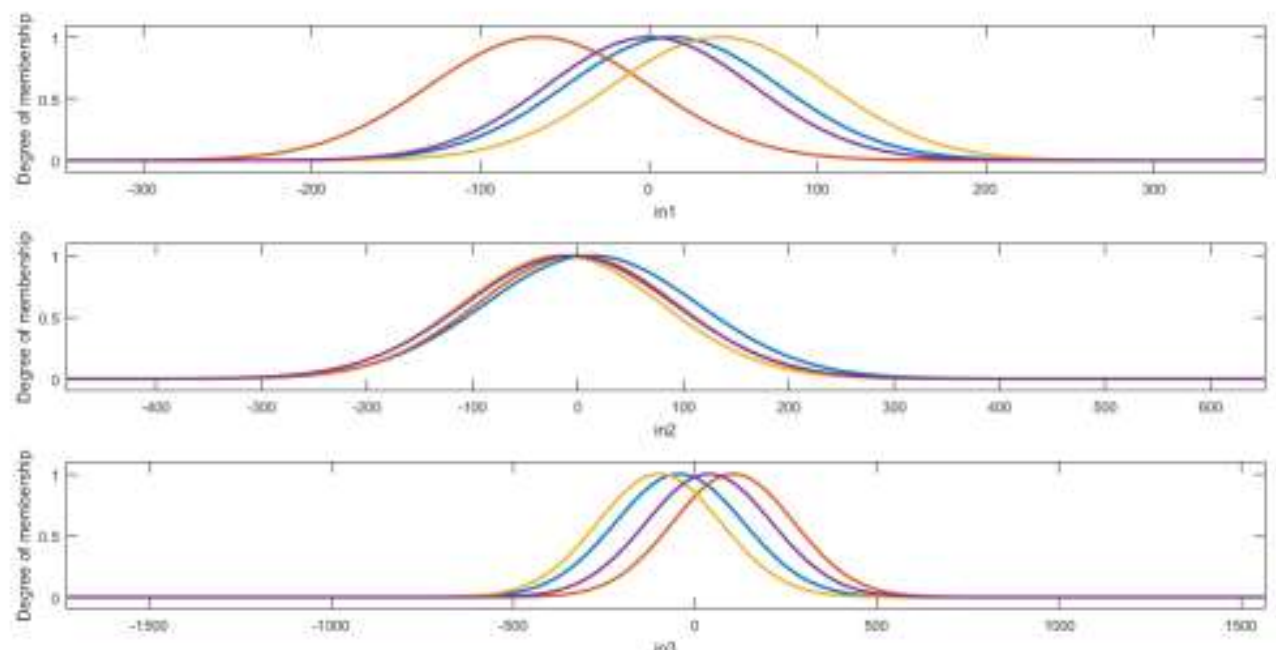

شكل • ا: توابع عضويت سه ورودى كنترل كر معكوس 
جدول r: برخى قواعد كنترل

\begin{tabular}{|c|c|}
\hline قاعده & شاعده \\
\hline $\begin{array}{l}\text { If (in1 is in 1c1) and (in2 is in2c1) and (in } 3 \text { is in } 3 \mathrm{c} 1) \text { and (in } 4 \text { is in } 4 \mathrm{c} 1) \text { and (in } 5 \text { is in } 5 \mathrm{c} 1 \text { ) and } \\
\text { (in6 is in } 6 \mathrm{c} 1) \text { then (out } 1 \text { is out } 1 \mathrm{c} 1)(\text { out } 2 \text { is out } 2 \mathrm{c} 1)(\text { out } 3 \text { is out } 3 \mathrm{c} 1)\end{array}$ & 1 \\
\hline $\begin{array}{l}\text { If (in1 is in } 1 \mathrm{c} 2) \text { and (in2 is in2c2) and (in } 3 \text { is in } 3 \mathrm{c} 2) \text { and (in } 4 \text { is in } 4 \mathrm{c} 2) \text { and (in } 5 \text { is in5c2) and } \\
\text { (in6 is in6c2) then (out } 1 \text { is out } 1 \mathrm{c} 2)(\text { out } 2 \text { is out } 2 \mathrm{c} 2)(\text { out } 3 \text { is out } 3 \mathrm{c} 2)\end{array}$ & $r$ \\
\hline $\begin{array}{l}\text { If (in } 1 \text { is in } 1 \mathrm{c} 3) \text { and (in2 is in2c3) and (in } 3 \text { is in } 3 \mathrm{c} 3) \text { and (in } 4 \text { is in } 4 \mathrm{c} 3) \text { and (in } 5 \text { is in } 5 \mathrm{c} 3) \text { and } \\
\text { (in6 is in6c3) then (out1 is out } 1 \mathrm{c} 3)(\text { out } 2 \text { is out } 2 \mathrm{c} 3)(\text { out } 3 \text { is out } 3 \mathrm{c} 3)\end{array}$ & $r$ \\
\hline
\end{tabular}

جدول "ّ: برخى قواعد كنترل كر خبره فازى

\begin{tabular}{|c|c|}
\hline قاعده & شاعده \\
\hline $\begin{array}{l}\text { If }(\mathrm{x} \text { is } \mathrm{Neg}) \text { and }(\mathrm{y} \text { is } \mathrm{Neg}) \text { and }(\mathrm{z} \text { is Neg) then }(\Delta m 1 \text { equals }-15)(\Delta m 2 \text { equals }-20)(\Delta m 3 \text { equals } \\
60)\end{array}$ & 1 \\
\hline $\begin{array}{l}\text { If ( } \mathrm{x} \text { is Neg) and ( } \mathrm{y} \text { is Neg) and ( } \mathrm{z} \text { is Zero) then }(\Delta m 1 \text { equals }-15)(\Delta m 2 \text { equals }-20)(\Delta m 3 \text { equals } \\
0)\end{array}$ & r \\
\hline $\begin{array}{l}\text { If ( } \mathrm{x} \text { is Neg) and ( } \mathrm{y} \text { is Neg) and }(\mathrm{z} \text { is Pos) then }(\Delta m 1 \text { equals }-15)(\Delta m 2 \text { equals }-20)(\Delta m 3 \text { equals - } \\
60)\end{array}$ & $r$ \\
\hline $\begin{array}{l}\text { If ( } \mathrm{x} \text { is } \mathrm{Neg}) \text { and (y is Zero) and ( } \mathrm{z} \text { is Neg) then }(\Delta m 1 \text { equals }-15)(\Delta m 2 \text { equals } 0)(\Delta m 3 \text { equals } \\
60)\end{array}$ & F \\
\hline If $(\mathrm{x}$ is Neg) and ( $\mathrm{y}$ is Zero) and ( $\mathrm{z}$ is Zero) then $(\Delta m 1$ equals -15$)(\Delta m 2$ equals 0$)(\Delta m 3$ equals 0$)$ & $\Delta$ \\
\hline
\end{tabular}
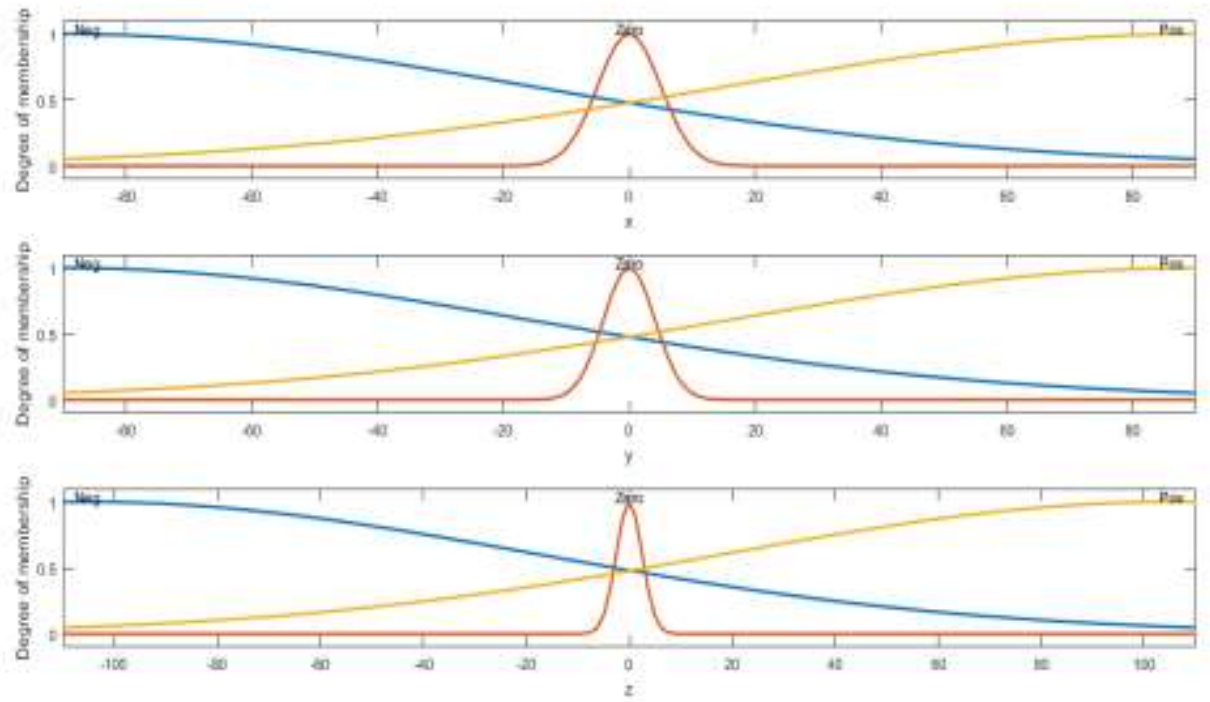

$$
\text { شكل 11:توابع عضويت ورودى كنترل كر خبره فازى }
$$

آن محدوده قرار گيرد هدف در دسترس آن قرار دارد. در آزمايش هاى

انجام شده اين محدوده به صورت [30,0-] ، [30,30-] و [-10,30-

$$
\text { در ابعاد y y و X Y تعريف شده است. }
$$

جدول \& خطاى سيستم در زمان استفاده از كنترلگر معكوس فازى

به تنهايى و كنترل كر تر كيبى فازى در ينج نقطه مختلف هدف، را با هم

مقايسه مى كند. براى تشخيص رسيدن مجرى نهايى به هدف ناحيه

محدودى اطراف هدف در نظر گرفته شده است كه اكر مجرى نهايى در 
است. بديهى است كه همانطور كه كفته شد، كنترل گر تركيبى ديخر

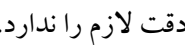

بعل از اعمال تغييرات در محيط حال نوبت به آموزش سيستم مىرسد. آموزش سيستم ماند آنجه است كه در بخش بـr آورده باشد. عمل بيشنهادى و نحوه به روزرسانى وزنها بر اساس روابط (11)، (14) و (15) صورت مى گيرد. مورد ديخرى اينكه سيكنال تقويتى براى محاسبه خطاى تفاضل موقت مورد نياز است. در آزمايشات صورت گرفته سيكنال تقويتى در نظر كرفته شده به صورت رابطه (16) است.

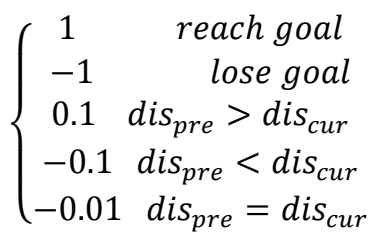

منظور از discur و dispre به ترتيب فاصله اقليدسى مجرى نهايى از هدف

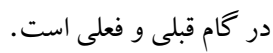

در روابط بروزرسانى وزن هاى عملكر و نقاد دو پارامتر نرخ

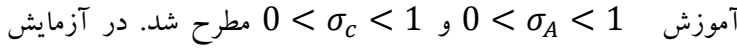

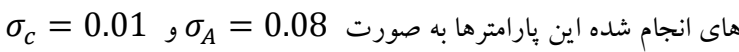
در نظر گرفته شده است. اين مقادير اكر خيلى كو جکك باشد، فرآيند

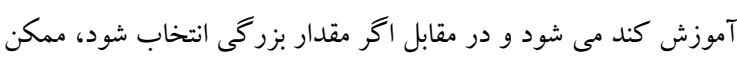
است منجر به نوسان بيرامون جواب بهينه شود. فرض شده است، زمانى كه سيتم در طى فر آيند آموزش به جايى

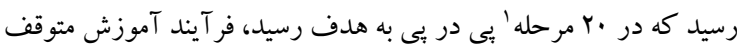
شد. با توجه به اين فرض، سيسم را \& \& مر حله، آموزش طول كشيده

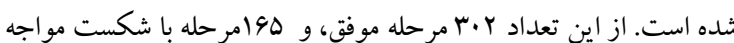

همانطور كه در جدول F نمايش داده شده، كنترل گر تركيبى خطا را كاهش داده و به هدف مىرساند. منظور از خطا فاصله مجرى هايى تا

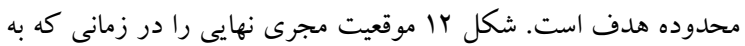
هدف رسيده و خطا صفر شده را نشان مى دهد.

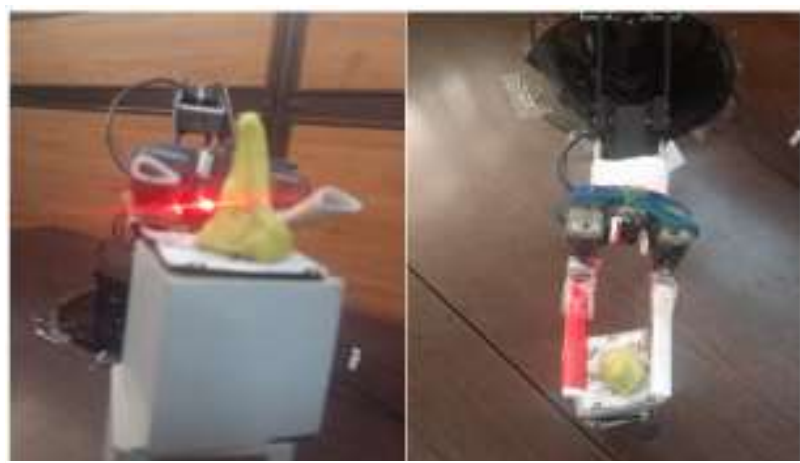

شكل r I : موقعيت مجرى نهايى در زمان رسيدن به هدف

\begin{tabular}{|c|c|c|c|c|}
\hline خطاى & خبل & بعلد $x$ (px) & كتترل كر & آزمايش \\
\hline . & - & $-r$. & معكوس & \multirow{2}{*}{1} \\
\hline \multicolumn{3}{|c|}{ reach } & تر كيبى & \\
\hline . & $\mu F$ & . & معكوس & \multirow{2}{*}{$r$} \\
\hline \multicolumn{3}{|c|}{ reach } & تر كيبى & \\
\hline $1 . r$ & $9 \pi$ & . & معكوس & \multirow{2}{*}{$r$} \\
\hline \multicolumn{3}{|c|}{ reach } & تركيبى & \\
\hline$-r \Delta$ & $\mathrm{kq}$ & $\Delta 9$ & معكوس & \multirow{2}{*}{$\varepsilon$} \\
\hline \multicolumn{3}{|c|}{ reach } & تر كيبى & \\
\hline iro & $\Lambda r$ & -r & معكوس & \multirow{2}{*}{0} \\
\hline \multicolumn{3}{|c|}{ reach } & تر كيبى & \\
\hline
\end{tabular}

جدول f: مقايسه دقت دو كنترل گر معكوس و تركيبى

\section{ع-r تنظيم بر خط كنترل}

در بخش r-r-r مطرح شد كه از ياد گيرى تقويتى و روش عملكر نقاد براى آموزش برخط تغييرات به سيستم و همجنين بهبود عملكرد كنترلگر خبره فازى استفاده شده است. به منظور يادگيرى تغييرات و براى انجام آزمايش ها در اين زمينه، ابتدا نياز است كه تغييراتى در سيستم و محيط كارى ربات ايجاد شود. لذا در اينجا تغييرى كه در محيط ايجاد شده، تغيير ده سانتى متر در موقعيت ميزى است كه ربات در آن قرار دارد. ميز به اندازه ده سانتى متر از ديوار فاصله كرفته و جلوتر قرار خرفته 

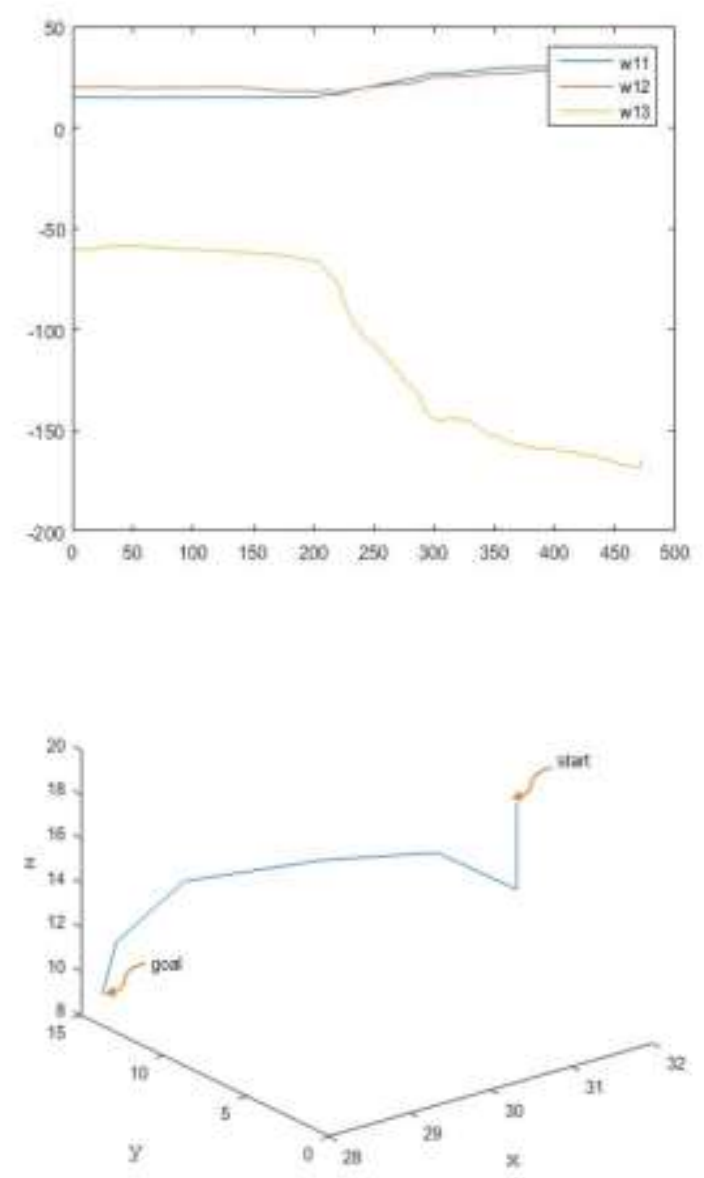

شكل ها:موقعيت مجرى نهايى در يكى از آزمايشات

\section{0- نتيجه كيرى}

در اين مقاله يك كنتر لخر تركيبى فازى براى رساندن مجرى نهايى بازوى ربات به هدف ارائه شد. اين كنترلخر شامل يك كنترل

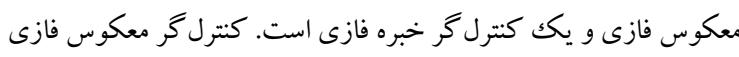
براى رساندن مجرى نهايى به اطرف هدف استفاده شد. آزمايشها نشان

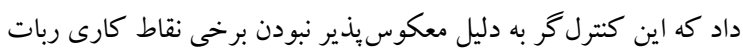
و خطاى موجود در جمع آورى اطلاعات، به تنهايى دقت كافى را دارا نيست. لذا براى رفع اين مشكل از كتترل گر خبره فازى در نواحى نزديك

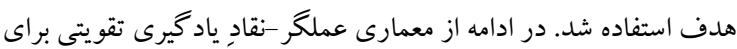
تنظيم بر خط كترل گر جهت تنظيم بهتر بارامترهاى كتترل گر خبره فازى و نيز قابليت تطبيقيذيرى سيستم استفاده شد. نتايج آزمايشهاى صورت كرفته نشان داد روش مذكور عملكرد

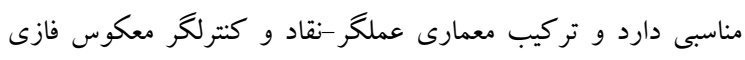

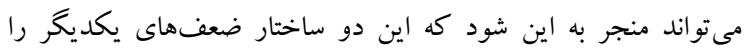

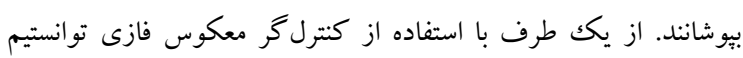

ع- r تست كنترل كر آموزش ديده به صورت برخط

زمانى كه به نظر رسيد كه سيستم به اندازه كافى آموزش ديده است، فرآيند آموزش متوقف و براى شش نقر نقطه از ييش تعيين شده براى تست،

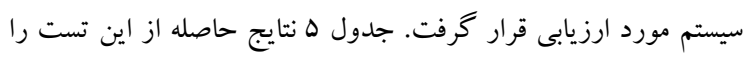

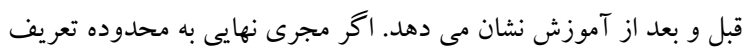

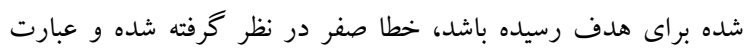

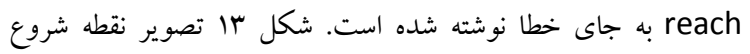
حركت و توقف مجرى نهايى در يكى از آزمايشها ذكر شده در جدول ندان ه را نمايش مىدهد.

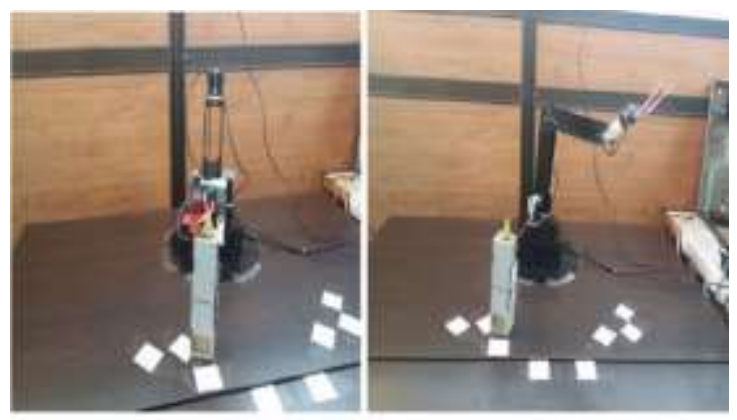

شكل با:موقعيت اوليه و پِيانى مجرى نهايى

جلدول ه: مقايسه عملكرد كنترل گكر قبل و بعد از آموزش

\begin{tabular}{|c|c|c|}
\hline خطاى كنترل & خطاى كنترلگر قبل & شماره آزمايش \\
\hline reach & {$[-6,22,14]$} & 1 \\
\hline reach & {$[0,29,13]$} & $r$ \\
\hline reach & {$[-9,19,18]$} & $r$ \\
\hline reach & {$[-4,-22,14]$} & r \\
\hline reach & {$[-19,-27,21]$} & $\Delta$ \\
\hline reach & {$[5,-3,26]$} & 4 \\
\hline
\end{tabular}

همانطور كه كفته شد، وزن هاى عملكر ابتدا به خروجى سيستم

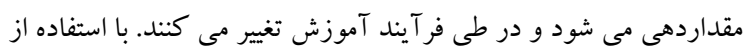

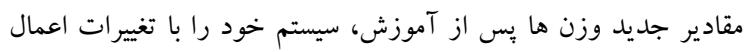

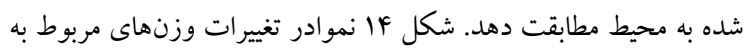

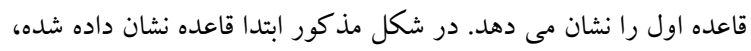

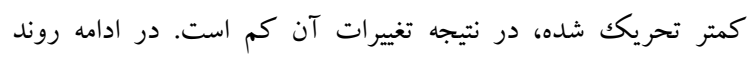

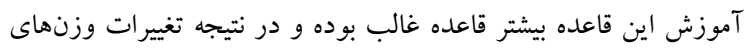

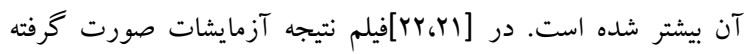
براى كنترل

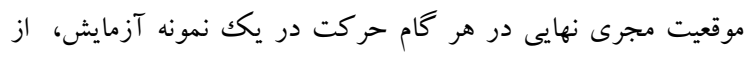
حالت اوليه تا رسيدن به هدف را نشان مى دهد. 
[8] Z. Miljkovic, M. Mitic, M. Lazarevic, and B. Babic, "Neural Network Reinforcement Learning for Visual Control of Robot Manipulators," Expert Systems with Applications, vol. 40, pp. 1721-1736, 2013.

[9] M. Deisenroth, C. Rasmussen, and D. Fox, "Learning to Control a Low-Cost Manipulator Using Data-Efficient Reinforcement Learning," International Conference on Robotics: Science \& Systems, pp. 57-64, 2011.

[10] Robotic Arms. (n.d.). Pishrorobot. [Online]. Available:http://www.pishrobot.com/en/products/robotic _arms.htm. Accessed 19 Aug 2016.

[11] Kinect | Xbox 360. Xbox.com. (n.d.). [Online]. Available: $\quad$ http://www.xbox.com/en-US/xbox360/accessories/kinect. Accessed 19 Aug 2016.

[12] J. Jang, C. Sun, and E. Mizutani, Neuro-fuzzy and Soft Computing. Upper Saddle River, NJ: Prentice Hall, 1997.

[13] S. Guillaume. "Designing Fuzzy Inference Systems from Data: An Interpretability-Oriented Review." IEEE Transactions on fuzzy systems, pp. 426-443, 2001.

[14] R. S. Sutton and A. G. Barto, "Introduction to Reinforcement Learning," IEEE Transactions on Robotics and Automation, MIT Press, 1998.

[15] L. P. Kaelbling, M. L. Littman, and A. W. Moore, "Reinforcement Learning: A survey," Journal of Artificial Intelligence Research, vol. 1, no. 1, pp. 237285, 1996.

[16] R. Sutton, and A. G. Barto, "Reinforcement learning," Journal of Cognitive Neuroscience, vol. 11, no. 1, pp. 126-134, 1999.

[17] X. S. Wang, Y. H. Cheng, and J. Q. Yi "A Fuzzy ActorCritic Reinforcement Learning Network," Journal of Information Sciences, vol. 177, pp. 3764-3781, 2007.

[18] L. X. Wang, (1997): A course in fuzzy systems and control. 1. Aufl. Upper Saddle River, NJ: Prentice Hall PTR.

[19] R. Babuska, Fuzzy Modeling for Control. Boston, MA: Kluwer Academic, 1998.

[20] FJ. Chang, and YT. Chang. "Adaptive Neuro-Fuzzy Inference System for Prediction of Water Level in Reservoir." Advances in Water Resources. pp. 1-10, 2006.

[21] Fuzzy hybrid control of robot with camera, aparat, 2016. [Online]. Available: http://www.aparat.com/v/5UWeh. Accessed: 08 Jul 2016.

[22] Fuzzy adaptive control of robot with camera, aparat, 2016. [Online]. Available: http://www.aparat.com/v/blqN0. Accessed: 17 Oct 2016.

$$
\begin{aligned}
& \text { فضاى آموزش و محدوده جستجو را در يادگيرى تقويتى كاهش داده و } \\
& \text { لذا سرعت يادگيرى را افزايش دهيم. لازم به ذكر است يكك ضعف } \\
& \text { روشهاى يادگيرى تقويتى نياز به تكراز زياد تجربيات است. رفع اين } \\
& \text { مشكل بخصوص در هنگام انجام آزمايش با يكك ربات واقعى (نه مدل }
\end{aligned}
$$

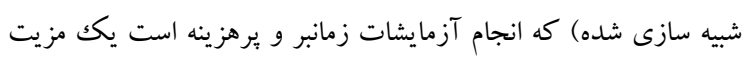

$$
\begin{aligned}
& \text { مهم به حساب مى آيد. از طرف ديگر استفاده از يادگيرى تقويتى امكان } \\
& \text { تنظيم برخط بِارامترهاى كنترلگر فازى و تطبيقيذيرى آن را را فراهم } \\
& \text { مى كند. } \\
& \text { از آنجايى كه براى گرفتن اطلاعات بصرى از كينكت استفاده شده، } \\
& \text { و دوربين كينكت در فضاى باز قابل استفاده نيست، لذا براى مسير آينده } \\
& \text { اين بزوهش مناسب است كه از دوربين معمولى و به صورت استريو، } \\
& \text { براى گرفتن اطلاعات از محيط استفاده شود تا بتوان از اين سيستم در } \\
& \text { فضاى باز نيز استفاده كرد. } \\
& \text { اجع }
\end{aligned}
$$

[1] D. Kragic, and H. Christensen, "Survey on Visual Servoing for Manipulation," Computational Vision and Active Perception Laboratory, Fiskartorpsv 15 ,2002.

[2] F. Nadi, "Visual Servoing Control of Robot Manipulator with Jacobian Matrix Estimation," (in Persian) M.S. Thesis, Faculty of Electrical and Computer Engineering, Yazd University 2014.

[3] P. Goncalves, L. Mendonca, J. Sousaand, and J. Pinto, "Uncalibrated Eye-to-Hand Visual Servoing Using Inverse Fuzzy Models," IEEE Transactions on Fuzzy Systems, pp. 341-353, 2008.

[4] C. Distante, A. Anglani, and F. Taurisano, "Target Reaching by Using Visual Information and Q-learning Controllers," Autonomous Robots, vol. 9, pp. 41-50, 2000.

[5] A. Anglani, F. Taurisano, R. De Giuseppe, C. Distante, and L. Lecce, "Learning to Grasp by Using Visual Information Robot System and Controller Architecture," Autonomous Robots, vol. 9, pp. 41-50, 2000.

[6] M. Sadeghzadeh, "Self-Learning Visual Servoing of Robot Manipulator Using Explanation-Based Fuzzy Neural Networks and Q-Learning," Ph.D. Dissertation, University of Guelph, 2014.

[7] K. Shibata, M. Sugisaka, and K. Ito, "Hand Reaching Movement Acquired Through Reinforcement Learning," in Proceedings of 2000 KACC (Korea Automatic Control Conference) ,2000. 